\title{
THE RHETORIC OF CRISIS: POLITICAL COMMUNICATION ON SOCIAL NETWORKS DURING THE 2020 CORONAVIRUS OUTBREAK
}

\author{
Antonia ENACHE ${ }^{1}$ \\ Marina MILITARU ${ }^{2}$
}

\begin{abstract}
The present paper analyses political communication on social platforms like Facebook, Twitter and Instagram during the 2020 coronavirus crisis. We are looking into the discourse of important political actors in the USA, Canada, France, the UK, the EU and Romania, attempting to highlight the rhetorical strategies they use to communicate with their audiences, to reassure them, to convince them that the crisis will be eventually overcome, to motivate and persuade them to comply with official regulations and to gain credibility and legitimacy for the policies enforced. The paper also provides an outline of the main advantages of using social platforms to reach the public, as well as of the most commonly used concepts and buzz-words that rhetors resort to in order to achieve their goals.
\end{abstract}

Keywords: coronavirus crisis, political communication, social media, togetherness, unity, action

DOI: $10.24818 / \mathrm{SYN} / 2021 / 17 / 1.06$

\section{Introductory remarks}

As we are writing the present paper, the 2020 coronavirus crisis is taking the world by storm, laying out a set of medical, economic, social and psychological problems no one was ready for. While the pandemic outbreak is first and foremost a medical tragedy, directly and indirectly affecting the lives of millions of people and bringing hospitals worldwide on the brink of collapse, its implications go beyond health systems, as the growing impact on economies is ever more visible, recession looms ahead, and at this point it seems inevitable that our outlook on life altogether will be completely overhauled. Against the challenge of a disruptive event of this magnitude, major political actors across the board are striving to understand the exact nature of the threat they are facing, correctly assess the situation on the ground, mitigate the damage caused by the pandemic, minimize people's exposure, and deal with the medical and economic crisis as best they can. However, considering the fact that audiences tend to be terrified, insecure about the future and distrustful of authorities, reassuring people, communicating with them and conveying the message

\footnotetext{
${ }^{1}$ Antonia Enache, Bucharest University of Economic Studies, antonia.enache@rei.ase.ro

${ }^{2}$ Marina Militaru, Bucharest University of Economic Studies, marina.militaru@rei.ase.ro
} 
that the predicament is being dealt with and will end in the foreseeable future is a task as important as solving the problem itself.

In light of the recent developments, political speakers need to skilfully craft their response to the unattractive, dangerous position they find themselves in, as the impressive media coverage alongside public expectations place huge pressure on their shoulders. These are not normal times; hence, communication occurs based on different patterns. Messages that reach the public sphere have to inform, persuade, reassure and win over audiences in more sophisticated, more compelling ways. On the one hand, it is important that recipients be convinced of the severity of the crisis, so that they cooperate and comply with governmental regulations. On the other hand, discourses aiming to frighten the audience without also conveying a touch of hope and optimism risk to backfire and result in unpredictable outcomes. Therefore, politicians tailor their rhetoric to respond to the complex, multi-faceted challenge.

In these times of crisis, discourse serves several intertwined purposes: it shows audiences that political leaders are fully aware of the problem, of its magnitude and its implications and are doing everything possible to get things back on the right track; it legitimizes the measures enforced, which are hugely restrictive and impact both individual freedom and personal welfare, ensuring support for them; it orients society towards the common goal, which is defeating the coronavirus, through a community-oriented narrative; it mobilises the listeners by appealing to their need for political involvement and participation, to their civic activism and their impatience to see their lives return to a more bearable status quo; last but not least, political discourse aims to mentally prepare the public for a possible major societal shift, for a new organization of life, work and social interaction that may shatter everything we knew about the world so far. In the present paper, we will look into political discourse on social platforms like Facebook, Twitter and Instagram, highlighting the main recurring discursive strategies as well as showing how messages are crafted in order to achieve their initiators' desired objectives.

For the purpose of our research, we have chosen extracts from the social media posts of some of the most important political actors worldwide: the then incumbent American president, Donald Trump, alongside the former presidential candidate Hillary Clinton for the USA, while the posts of the French president Emmanuel Macron, of British Prime Minister Boris Johnson, of the President of the European Commission, Ursula von der Leyen and of the Romanian president, Klaus Iohannis, have been selected as samples of the discursive strategies used in Europe. On a related note, we have also referred to the British Queen's historic speech on the coronavirus crisis, broadcast on April 5, 2020 - though it was not a social media post, we found it relevant for our research and we cited it to show how its ideas were in total harmony with the points the other politicians attempted to make. We have also cited the Instagram posts of the Canadian Prime Minister, Justin Trudeau, aiming to prove that, during the coronavirus crisis, political communication across 
the board pursued the same persuasive strategies, emphasizing the need to understand the gravity of the situation, to stay united and to take a pro-active stance, thus highlighting the importance of responsibility, involvement, selflessness and action. Not only were the selected politicians in public office at the moment the paper was written, they were also public figures with significant social reach whose views and recommendations were likely to be taken seriously and followed to a great extent.

Broadly speaking, our analysis fits the framework of a Critical Discourse Analysis approach, in that it "focuses primarily on social problems and political issues" (Van Dijk, 2004: 353) that are of utmost relevance at the present moment, it tackles political communication in an interdisciplinary manner, incorporating elements of linguistics, rhetoric, pragmatics and discourse analysis, and it views discourse as "a form of social action" (Van Dijk, 2004: 353) and a means of generating and strengthening mentalities and ideologies.

Moreover, "one of the core goals of political discourse analysis is to seek out ways in which language choice is manipulated for specific political effect". (Wilson, 2004: 410) We are therefore looking into the linguistic choices speakers make, as well as into the discursive strategies they use when aiming to reinforce the depth of a particular stringent crisis and to steer the audience towards ways of overcoming it.

On social media in particular, language becomes "an interactive activity mediating linguistic and sociocultural knowledge" (Schiffrin, 1998: 415) with a view to conveying ideas, proposing courses of action, gaining adepts, building up political support and collecting feedback.

Since "in media discourse, as well as generally in writing, there is a sharp divide between producers and interpreters - or, since the media «product» takes on some of the nature of a commodity between producers and "consumers»" (Fairclough, 1989: 49), in our present research, we attempt to shed light on the main concepts politicians "sell" during the initial stages of the Covid-19 pandemic outbreak, on the discursive strategies they use to sugarcoat the message (which is likely to bring about a negative reaction from the audience) and on the recurring ideas put forward in order to shape new mentalities and prepare the shift towards an incipient social paradigm.

\section{Political communication on social networks}

In the IT-centred era we now live in, the old means of communication used by politicians, such as television and the written press, have gradually lost their importance and have been replaced by communication on the internet. To the extent to which more and more people turn to the online as their main source of information, political communicators too have had to adapt their discourse and their persuasive 
strategies, taking into account this societal shift. Network technologies have now become the primary means of communication for public and political debates, equally.

Thus, while old communication channels have become obsolete and have steadily been phased out, social networking sites like Facebook, Twitter and Instagram have turned into the most commonly used ways in which politicians reach their audience. They are used to connect with all audiences, but primarily with young people, supporters and potential voters; political actors resort to these networks to raise awareness of their most important projects, to communicate their policies, convey their standpoint on topical issues and obtain feedback from the followers. Social media has a profound influence on politics, impacting the distribution, reception and sharing of information. Consumers have the freedom to easily access the news and to choose the content they agree with; thus, social media "stimulates and activates citizen political participation while also contributing to political polarization and more extreme political attitudes and issue positions". (Gainous and Wagner, 2014: 15) We can undoubtedly state that the advent of social networking as the primary means of communication has given everyone a voice, the enhanced possibility to keep up with the events unfolding on the political arena as well as the means to make their opinion visible.

If we were to analyse the main reasons why social media platforms have become so widely used by political actors, the following stand out as crucially important.

Firstly, posts on social networks can be (and sometimes must be) short, concise, conveying the gist of the matter. If the same idea is expressed in a concentrated paragraph rather than a longer text, readers tend to remember it more vividly. Political and commercial slogans, or mission statements, work according to the same principle. Concision gives a message its power, its ability to impact the receiver, hence functioning as a compelling persuasive tool.

Secondly, social media provides an unprecedented level of interactivity between the political actor and their followers, which in its turn results in a twofold benefit for users. On the one hand, they can express their opinion and thus feel that they have a personal relationship with the political actor (although the impression may be false, since the latter usually has a campaign staff managing their presence online); on the other hand, users can participate in discussions with others and engage in social interactions with people who may or may not feel the same way about the issues at stake. Therefore, social media allows for self-expression and the possibility to share opinions (Denton, Trent and Friedenberg, 2020: 340) in a fast, effective way. Interactivity also benefits political actors, as they can, to some extent, take the pulse of society and assess the impact and popularity of their posts. 
Thirdly, social media comes along with a powerful visual dimension, due to the easy option of posting pictures or videos that viewers can access right away. There is nothing like the power of visual content to capture the audience's attention and provoke a reaction. Images are processed faster than the written text, arouse emotions instantly and are best remembered in time. Visual content helps raise awareness and establish memory, while also contributing to building up a lasting identity of the political actor; logos, symbols, form and colour all contribute to their "branding" process (Lilleker, 2006: 42).

Last but not least, social media significantly contributes to the infotainment dimension that dominates civic life in the age of the internet or, in other words, to the practice of combining information and entertainment in the broadcasting of news and public affairs (Lilleker, 2006: 99-102). Eager to win over supporters and ensure future votes, politicians are stepping down from their pedestal and communicating news in ways that have become more entertaining and media-friendly. In this respect, it is not only the visual aspect that matters, it is also the use of language, which has become less academic and more informal. Infotainment contributes to a political actor's image in that they come across as more authentic, closer to the public, more likely to understand the latter's needs and therefore more reliable.

To sum up, we can say that political communication in recent years has adapted to the changes in society and technology, adjusting both the form and the content of the message accordingly. The use of social media allows for convenience, precision, easy access to information, social interaction, entertainment and personal decisionmaking in ways that would have been unconceivable in the past. In the "multi-screen world" (Merchan, 2018), communication with the audience has to occur primarily through the screens that are most commonly used and to respond to the expectations of their users.

\section{Communication during the coronavirus crisis}

During the 2020 coronavirus predicament, which is unfolding as we write the present paper, the discourse of politicians functions according to a different set of rules, namely those that apply in times of crisis. When normal circumstances change to such an extent that they hugely impact societies worldwide, communication patterns shift in order to respond to the enhanced emotional needs of the audience - "every social upheaval distorts customary communication patterns and makes it necessary to overhaul them" (Potsar, 2016: 17), as crises are complex communicative events that need to be acknowledged as such. The state, which plays the main role in the establishment and implementation of public policies, has to recognize the existence of the crisis and constantly communicate to the public the measures taken; the process plays a threefold role, since firstly, citizens need to be informed of the status quo; secondly, they need to be reassured that things are on the right track and that 
the crisis will be eventually overcome. Finally, since the implemented state of emergency requires measures severely affecting human rights, the political actors' discourse needs to reinforce the need for these measures, bestowing legitimacy upon them and ensuring public support. Informing, convincing, persuading and effectively putting the message across are significantly more important in times of crisis than in normal times.

As a crisis has been defined as "a time of great danger or trouble", its consequences instantly make their way into the sphere of communication, "demanding a common agenda and public dialogue to negotiate collective actions aimed at changing the situation". (Potsar, 2016: 20) Political decisions, often unpopular, have to come across as not only appropriate and necessary, but above all else, essential for survival. In such extreme situations, more than ever, it is crucial that the public should feel they are included in the decision-making process.

The overhaul of communication patterns has to take into account, primarily, the increased emotionalization of the context. Due to their overwhelming fear, people's rational reactions give way to strongly emotional ones. In this particular case, fear functions along two dimensions. On the one hand, people are afraid of the virus itself, of what it could do to their lives and to the lives of their loved ones and, ultimately, they are afraid of dying. On the other hand, there are powerful economic concerns in place, as the financial impact of economies closing down is bound to result in recession. As we are writing the current paper, millions of people worldwide have already lost their jobs, other millions feel insecure about the future, while the crisis will most likely continue to deepen. Hence, political actors need to respond to the public's concerns, and the rhetoric of crisis has duly taken on several characteristic features.

Firstly, vague, ambiguous or equivocal utterances are almost absent from social media communication, and have been replaced by concise messages across the board. Argumentation is powerful, specific and to the point. The discourse of political actors revolves around the notion of responsibility, translating into a specific set of recommended measures such as washing your hands, staying at home and complying with social distancing requirements, all with a view to flattening the infection spread curve ${ }^{3}$, diminishing pressure on medical systems and eventually saving lives. Our entire lives have already changed within the borders of the new crisis paradigm; social identity is likely to be completely redefined in the future as well, as are behaviours considered acceptable and eventually, our approach to life and society altogether. Rising social unrest, alongside a marked state of panic, are given the answer of a new paradigm, wherein identities and cultures are reconfigured to adjust to a future as yet uncertain.

3 "Flattening the Coronavirus Curve", retrieved from https://www.nytimes.com/article/ flatten-curve-coronavirus.html, accessed on April 4, 2020. 
In the following section of our paper, we shall analyse the discourse of political actors in several countries (the USA, Canada, France, the UK and Romania), focusing on how they attempt to tackle the crisis and communicate with their audience. We shall focus on two appeals that appear to be of utmost importance in the rhetoric of speakers across the board: the appeal to unity, togetherness, and approaching the problem in a community-like manner, and the appeal to action, to get involved in a pro-active way, to participate in the joint efforts of people, states and institutions worldwide in order to put an end to the predicament as soon as possible. The last extract we will look into represents an Instagram post by Ursula von der Leyen, the current President of the European Commission, and we will show that the discourse of supranational organisations representatives reinforces that of national leaders, bestowing legitimacy upon the latter and setting the stage for the emergence of a new, still unclear social paradigm.

\subsection{The appeal to unity and togetherness}

Political communication generally targets audiences who think of themselves as citizens; therefore, it must be tailored to inform, persuade and win over people who feel some degree of connection with, and involvement in social and political life. In the coronavirus context, out of the many buzz-words that politicians resort to in order to convey messages to their public, appeals to unity and togetherness stand out as some of the most frequently used ones.

Unity is inherently desirable at all times, perhaps even more so in the global world, where countries seem to have lost national sovereignty to the powers of supranational organizations. However, never does the appeal to unity appear to be more powerful than in times of crises, when panic reigns supreme and people need further incentives to acquiesce to a brutally enforced status quo. The appeal to cooperation, to dropping all contention and bickering between political factions or social categories, which is a fundamentally emotional one, overpowers all other messages that make their way into the political arena.

In the particular case of the coronavirus crisis, the urge to stand together taps into our negative emotion of fear. Appealing to the audience's emotions is an effective strategy, especially in times of crisis; "generally negative emotions, such as fear, distrust, and ager, are stronger motivators than positive emotions, such as hope or pride". (Helfert, 2018: 79) In this atypical context, political communicators who develop their messages are saying things in the way that has the most chances of making the audience respond as they are expected to. We shall see, in sub-section 3.2. of our paper, that togetherness in not so much a goal in itself as it is a means to an end, setting the stage for a course of action to be followed. 
It is interesting to notice that, in the context of total reclusion, the appeal to unity and togetherness, in spirit if not in reality, has been enhanced by the fact that, due to the imposed or required social distancing, people can no longer be together physically. Therefore, faced with the challenge of physical separation, the appeal to solidarity becomes ever more powerful. Painful isolation increases people's emotional response to concepts playing on the idea of a community, while at the same time, against the background of personal loneliness, the idea of joining in a common effort to overcome the crisis appears to be powerful and enticing. Thus, the appeal to the concept of togetherness functions along two main dimensions: its abstract characteristic and its pro-active implications.

Ex. 1 .

The next several weeks may be some of the hardest we've faced as a country. From those on the front lines to those saving lives by staying at home, let's remember to be kind to each other, be patient, and remember the power of our collective humanity, even when we're apart. (Hillary Clinton, Twitter, March 30, 2020 ${ }^{4}$ )

Despite her unexpectedly losing the 2016 presidential elections, Hillary Clinton is still a prominent figure in American social and political life; also, due to her outstanding, lifelong professional accomplishments (she was, amongst others, the first American first lady to ever win a public office seat in 2001, when she was elected to the US senate, and the first woman in US history ascending to presidential nominee of one of the two major political parties), she will always remain a powerful, influential voice in the political world. More importantly, it is the very fact that her public discourse is no longer shaped by electoral stakes that confers weight and credibility upon it. Thus, the extract above is typical of what communication looks like in times of crises. Successful communication on the political arena cannot occur in the absence of a streak of optimism, since this type of message always draws on the public's infinite resources of hope. However, alongside optimism, and for the discourse to reach its desired emotional impact, resorting to negative emotions such as fear also plays a powerful role. In dramatic circumstances, which are atypical, capitalizing on fear overrides the optimistic outlook.

Unity makes its way as an underlying appeal even when it is not the main topic of discourse. In the above, while the speaker conveys explicit concerns about the future, warning the audience of the hardships yet to come, she pleads for kindness and solidarity, for people complying with the authorities' demands, while the appeal for unity is there as well, and unity is made to look even more desirable by the fact that it cannot be physically accomplished (social distancing inherently means that, physically, people cannot be together). The rhetor plays on the dichotomy together /

\footnotetext{
${ }^{4}$ https://twitter.com/HillaryClinton, accessed on April 20, 2020.
} 
apart, wrapping her call for solidarity into an emotional coating: mentioning abstract values like patience and kindness aims to establish a connection with the audience and convey the message that she is there for them, that she understands and shares their wailings.

Ex. 2 .

We're all in this together. I have never seen anything like it. (TeamTrump ${ }^{5}$, Twitter, March 30, 2020).

Unlike Hillary Clinton, Trump has to craft his discourse taking into account electoral considerations, since the 2020 presidential elections are fast approaching and he is running for a second term of office. Moreover, the incumbent American president has already been extensively criticized for having responded to the crisis in a slow and ineffective way, "failing to quickly embrace public health measures that could have prevented the disease from spreading". (Shear and McNeil Jr., 2020) Therefore, in light of his own agenda and of the public perception of his actions so far, communication with his audience is of the utmost importance - he has to pay increased attention to what he says and how he says it.

Example (2) is very short, which increases its impact. Two main ideas undistinguishably stem from it. On the one hand, togetherness is emphasized to the point where it becomes an imperative; due to the shortness of the extract, we are led to infer that it is an urge to act in any way to stop the crisis; on the other hand, by highlighting the fact that the situation is unprecedented, the communicator wishes not only to raise awareness, but also, again, to propel people to act. Generating and maintaining panic is not a gratuitous undertaking; by contrast, it is a strategy designed with a specific goal in mind. In this case, the goal translates into mobilizing everyone to prepare psychologically and to do their part in order to put an end to the crisis as soon as possible.

"Just as important as crafting the right message is making sure it gets to the right audience with sufficient repetition and reinforcement to persuade the undecided and motivate the committed" (Helfert, 2018: 108) However, repetition has to be done wisely in order to be impactful. While the incessant repetition of the main themes of discourse is crucial for the message to get through (Domenach, 2004: 76), variations in form, explanations of the main ideas and occasional elaborations constitute a necessary condition for audiences not to become irritated and for the gist of discourse to achieve its desired effect. In the above, though no concrete course of action is mentioned explicitly, the pro-active stance that audiences are expected to take

\footnotetext{
${ }^{5}$ https://twitter.com/TeamTrump, accessed on May 4, 2020 (Team Trump was the official Twitter profile for Donald Trump's 2020 presidential campaign).
} 
implicitly follow form the speaker emphasizing both the existence of danger and the need for togetherness.

Ex. $3 a$

Am intrat, de câteva zile, în cea mai grea etapă a acestei complicate perioade generate de epidemia de coronavirus. Este esențial să fim toți conștienți de acest lucru, pentru că vor veni momente cu o mare încărcătură emoțională, care ne vor testa solidaritatea şi unitatea. (Klaus Iohannis, Facebook, April 3, 2020)

(A few days ago, we entered the most difficult stage of this complicated period that the coronavirus epidemic has spawned. It is essential that we all be aware of this fact, as we are approaching emotionally charged moments that will test our solidarity and unity).

The Romanian President, Klaus Iohannis, is not bound by electoral restrictions himself, as he has already recently won a second term of office by a landslide victory (66,09 of cast ballots); however, as legislative elections are scheduled to take place in late 2020 or early 2021, nor is he completely free from political calculations, as an important number of future voters are likely to make their final decision of which faction to support based on how the authorities handle the coronavirus crisis. Besides, he, like all political actors, needs to respond to the requirements of permanent campaigning - the constant endeavour of elected individuals and organisations to "build and maintain popular support" (Lilleker, 2006: 143). Therefore, the Romanian speaker comes forth with a discourse playing on both rational and emotional arguments, in an attempt to inform, reassure and persuade his social media followers that everything is under control.

In a manner similar to that of extract 2 , extract $3 \mathrm{a}$ emphasises the importance of togetherness against the background of a serious, life-threatening danger. The speaker masterfully taps into the audience's negative emotions of insecurity and fear, attempting to gain legitimacy for the set of unpopular measures already enforced as well as for what is yet to come. It goes without saying that, since the policies implemented to combat the coronavirus menace brutally impact both individual liberties and national economies, political actors need to constantly convince their audience that the alternative would be much worse. This reference to an either / or spectrum, where it eventually boils down to choosing between one's life and one's freedom / welfare can be either explicit or implicit. In extract (3), it is explicit, as the speaker goes on to say that

Ex. $3 b$

Avem deja de deplâns 116 morți. 116 semeni de-ai noștri și-au pierdut viața răpuşi de acest virus. Oare câte victime va mai face epidemia? Nu știm! Dar știm sigur că depinde de noi să avem cât se poate de puține! Dacă nu respectăm cu strictețe toate măsurile impuse de autorități, pierderile de vieți omenești vor fi din ce in ce mai 
multe și cazurile grave, care necesită tratament medical intensiv, se vor înmulți. (Klaus Iohannis, Facebook, April 3, 20206).

(We are already mourning 116 deaths. 116 of our people have lost their lives, struck down by this virus. How many more victims will the epidemic claim? We do not know! But we do know that it is up to us to keep that number as low as possible! If we do not strictly comply with all the measures enforced by the authorities, the loss of human lives will be higher and the severe cases requiring intensive medical care will increase.)

The emotional impact of extract 3(b) cannot be overstated. The speaker initially gives an exact number, that of people who have died from the coronavirus, a fact which aims to convey factual certainty, then puts the emotional spin on things, therefore frightening the audience. Both reason and emotion are thus targeted: the readers are first given the fact, then the emotional rhetoric: our people, struck down. Then follows a rhetorical question, a powerful thought-provoking and eventually persuasive tool, whose goal is to assert a point implicitly and convey an idea that might be challenged, or might come across as excessively audacious if asserted directly. In this case, the rhetorical question arises against a very fertile background, since uncertainty already pervades people's lives on all levels: medical, economic, psychological, professional, social. Finally, as tension has reached a peak, we are given the either / or dichotomy, explicitly put forward. The audience is presented with a choice between complying with the restrictive measures and risking their lives. Considering the compelling, widespread media coverage that the collapse of the medical systems in other European countries (mostly Italy and Spain) has received, we can safely assume that any member of the audience would opt for the restrictions and the economic difficulties rather than for ending up in hospital and facing an uncertain outcome.

The more severe the restrictions, the more important rhetoric becomes in convincing the audience that the implemented policies are appropriate and in persuading them to cooperate. "Political parties and government agencies employ publicists of various kinds, whose role is not merely to control the flow of, and access to information, but also to design and monitor wordings and phrasings, and in this way to respond to challenges and potential challenges." (Chilton, 2006: 8). In an international context that shatters life as we know it and which is likely to change the paradigm of our existence forever, the coronavirus crisis must be framed in such a way that all implemented policies, however harsh or controversial, appear as legitimate.

Fear constitutes an emotion that takes its toll not only on the public, but on political actors as well. Faced with the choice between applying hugely restrictive policies and taking a more relaxed stance on a potential catastrophe, politicians simply cannot

${ }^{6}$ https://www.facebook.com/klausiohannis, accessed on May 7, 2020. 
afford the risks associated with the latter possibility. Not only could the coronavirus crisis result in a massive loss of lives, it could also cost them the elections, perhaps even more so than the looming economic recession. Hence, in the impossible situation, they prefer the lesser evil: applying the restrictive measures and crafting discourse accordingly in order to bestow legitimacy and credibility upon their actions.

Ex. 4.

It is with that great British spirit that we will beat coronavirus and we will beat it together. (Boris Johnson, Instagram, April 1, 20207).

Ex. 5. Every one of us has a role to play in protecting our loved ones, our front line workers, and our country from the threat we now face. And even though we must stand apart to stay safe, we must stand united to defeat COVID-19. (Justin Trudeau, Instagram, April 12, 2020 ${ }^{8}$ )

Similarly, extracts 4 and 5 emphasize the importance of togetherness, of combatting the crisis in a community-oriented manner. All political speakers across the board capitalize on each opportunity they get to reach the public, in order to convey the gravity of the coronavirus crisis. To do so, they transmit messages quickly whenever something new has occurred, they communicate constantly and they do so in a clear, concise and vivid manner. However, in this particular case, given the magnitude of the problem as well as its overwhelming impact on people's lives, emotions are as important as facts themselves. Emotions function in a threefold way: firstly, the political speaker needs to prove their full involvement, their commitment and dedication to overcoming both the medical and the economic crisis. Secondly, it is equally important to express hope, to boost people's morale and to assure them that their efforts and sacrifice will result in a better status quo, albeit a delayed one; in other words, the certainty that there will be a foreseeable end to the nightmare is crucial for the third purpose of communication, which is to propel the audience to act, to do their part so as to see victory come forth sooner rather than later.

Example (4) is more complex, in that it appeals to the British people's national pride, alongside stressing the importance of togetherness. In political communication, rhetors often resort to abstract concepts that are likely to arouse the audience's emotional response, as our emotions weigh more than our rational persona in the decisions we make as citizens. In times of crisis more than ever, political speakers turn to buzz-words that the audience can relate to, aiming for a quick and efficient reaction. National pride runs strong with the British, given their history and traditions; even if older generations take more pride in their origins than younger ones (Bailey, 2018), the prime minister's appeal is still likely to strike a chord with

\footnotetext{
${ }^{7} \mathrm{https}: / /$ www.instagram.com/p/B-byJwVA0_C/, accessed on May 8, 2020.

${ }^{8} \mathrm{https} / / /$ www.instagram.com/p/B-22HTTgmt4/, accessed on May 9, 2020.
} 
his Instagram followers. In fact, the Queen herself implicitly referred to the same ideals when she said, in her April 5 speech, that "those who come after us will say the Britons of this generation were as strong as any" . While the Queen put forward her message on television, targeting a larger audience, the Prime Minister conveyed the same appeal to national pride to a more restricted, younger public. However, one must not downplay the impact of his call, whose heartfelt honesty and commitment appear even more obvious in light of the fact that, in the earlier stages of the crisis, he had advocated a "herd immunity" (Matthews, 2020) approach, more relaxed, with fewer restrictions and higher risks for the population. He subsequently changed his viewpoint, adopting policies more in line with the international ones, and his original stance came under even more scrutiny as the prime minister himself contracted the virus and ended up in intensive care on April 7.

In example (5), the Canadian Prime Minister Justin Trudeau, who has also recently won the elections, albeit by a narrow victory, and is currently enjoying extensive public support for how he has been handling the coronavirus predicament (Little, 2020), plays on the dichotomy together/ apart in order to both reinforce the importance of complying with the enforced regulations, however unpleasant they might be, and emphasise the importance of a joint approach. In fact, the idea that, the more obedient we are, the sooner the restrictions will be lifted has surfaced in the discourse of political actors across the board, all through the coronavirus crisis, thus functioning as an incentive to obey the law, but also reminding audiences worldwide of the significant danger we are all facing. It is interesting to notice that Trudeau's discourse in extract (5), while placing emphasis on togetherness, also sheds light on the importance of the individual, on what each of us can do to avert disaster. Therefore, it would be fair to say that, in a very brief, concise stretch of discourse, the Canadian rhetor invokes all the major themes of the coronavirus crisis that are likely to impact the audiences: the idea of danger (the threat we now face), the dichotomy community (stand united) vs. individual (every one of us), the dichotomy together (stand united) vs apart (stand apart), the appeal to support those actively fighting the virus (our front line workers) and protecting those we love (protecting our loved ones). Last but not least, from this skilfully crafted piece of rhetoric, we can infer that the joint approach is an active one, that there is a fight going on, wherein we must all participate, and whose outcome depends on community as well as individual action, as we shall see in the following subsection of our paper.

\subsection{The appeal to action}

We have seen, in section 3.1., that political speakers worldwide have joined in a compelling, universal appeal that people should stand together and be united in the

9 The Queen's full speech can be accessed at https://www.bbc.com/news/uk-52176209 (viewed on April 11, 2020). 
coronavirus crisis. However, unity, cooperation and togetherness are not perceived as a goal in themselves; instead, they are but a means to an end. Governments and supranational organisations equally have conveyed an explicit set of recommendations to the public, which are repeated incessantly via all communication channels, both under the form of videos and written messages, and through the voice of political actors. The most commonly known ones include, as we all know, staying at home, paying attention to personal hygiene (especially washing our hands) and observing social distancing, all with a view to saving lives (an urge that is also omnipresent in the media). Considering the fact that "saving lives" is in itself an abstract appeal, in many cases political actors translate it into concrete steps to be taken.

Ex. 6

Emmanuel Macron: Toutes les 8 minutes, vous sauvez une vie. Restez chez vous. (Emmanuel Macron, Facebook, April 11, 2020 ${ }^{10}$ )

(Every 8 minutes, you save a life. Stay at home.)

The French president's popularity has soared in the wake of the Covid-19 predicament. His leadership style was widely criticized during the Yellow Vests protests and the pensions strikes; however, when the pandemic broke out, due to his firm approach, to the measures rapidly implemented and to the massive state intervention in handling the problem, he benefitted from an "astonishing popularity surge". (Wheeldon, 2020) Macron's discourse is in line with his policies; thus, his use of the war metaphor (we are at war), alongside the policies applied, both medically and economically, propelled him to the frontline of political leaders with a powerful stance against the virus and massive popular support.

Staying at home, avoiding unnecessary trips and staying away from crowded places have thus become the norm in the coronavirus era. "Persuasion can only occur when the message sufficiently connects with things the audience cares about in order to be received, considered, and accepted". (Helfert, 2018: 67) In the crisis the world is undergoing as we speak, three things are of the utmost importance. Firstly, there is the threat of the virus itself, which has taken countless lives and is menacing everyone's health and challenging the logistic capacity of hospitals worldwide. Secondly, there is the looming economic recession that the extensive lockdown is sure to bring about. And thirdly, one cannot overlook the social and psychological impact of the severe restrictions enforced on the population, restrictions that forbid human interaction and deeply affect personal wellbeing. Against this complex background, persuasion has to occur at the simplest, most fundamental level: that of simple, concise utterances, clear guidelines, and explanations everyone can relate to. For every abstract urge, such as saving lives, a concrete explanation must exist, even if it may not be reiterated on every occasion.

${ }^{10} \mathrm{https}: / / w w w . f a c e b o o k . c o m / E m m a n u e l M a c r o n$, accessed on May 11, 2010. 
Hence, in extract 6, the French president, one of the most fervent supporters of quarantine and social distancing, puts forward an explanation that stands out as atypical, since it refers to a specific temporal rate at which lives can be saved. Macron most certainly contends that each individual's staying home results in a life gained every 8 minutes relying on statistical studies; however, rarely does the public have the patience and the interest to do the respective research; also, it would be less impactful to explain further or give additional details; it is the shortest, simplest phrases that have the most significant effect. In that respect, social media platforms are helpful, as they enable a highly concise, slogan-like type of communication.

Ex. $7 a$

I want to express our tremendous thanks to the American people for continuing to practice social distancing, maintain good hygiene, and follow government guidelines - your commitment will make all the difference. (Donald Trump, Instagram, March 31, 2020 ${ }^{11}$ )

Ex. $7 b$

Our country in in the midst of a national trial - and success will require the full measure of our strength, love, and devotion. (Donald Trump, Instagram, April 1, $\left.2020^{12}\right)$

Ex. $7 c$

The data is clear: Our collective national effort is saving many lives. Keep up the fight! (The White House, Twitter, April 10, 202013)

Ex. 7d

The Invisible Enemy will soon be in full retreat! (Donald Trump, Twitter, April 10, $2020^{14}$ )

The urge to act is a complex one, incorporating several types of guidelines. On the one hand, the concrete recommendations recur obsessively in the discourse of political actors worldwide, in many cases accompanied by the abstract appeal to save lives. On the other hand, buzzwords with a powerful emotional potential are frequently used to enhance the impact of the message and to avoid repetitiveness. Thus, in example 7a, we see the American president thanking the population for complying with the sanitary requirements, alongside using the abstract buzzword

\footnotetext{
${ }^{11} \mathrm{https}: / /$ www.instagram.com/p/B-YKboQho8A/?igshid=ibe084reo9d2, accessed on May 12, 2020.

${ }^{12} \mathrm{https}: / /$ www.instagram.com/p/B-apLM3hldY/?igshid=1 oa4wq8thrp2e, accessed on May $12,2020$.

${ }^{13} \mathrm{https}: / /$ twitter.com/WhiteHouse45, accessed on May 14, 2020.

${ }^{14} \mathrm{https}$ ://twitter.com/realDonaldTrump, accessed on May 14, 2020.
} 
commitment, thus aiming to motivate the audience (motivational, morale-lifting rhetorical strategies abound throughout this period). In example $7 \mathrm{~b}$, the same speaker emphasizes how serious and widespread the problem is, resorting solely to abstract values as crucial in order to overcome it (love, devotion, strength). In example 7c, reference to concrete data is also intended to boost optimism, this time supported by clear scientific facts, while in extract $7 \mathrm{~d}$, the virus is personified twice (firstly by the use of the noun enemy, secondly by the use of capital letters). Thus, the terrible virus becomes a person, taking on new, humanlike characteristics - the approach is in line with the metaphor most frequently used throughout the crisis, that of the war ("we are at war" is a sentence audiences everywhere have frequently heard since the debut of the pandemic).

Personification stands out as a compelling rhetorical strategy that shifts the recipient's mindset; in this case, if people think of coronavirus as a persona rather than an inanimate entity, the efforts to combat it are likely to intensify. In the American president's discourse, we can see a blend of fear and optimism, of attempts to raise awareness, generate action and boost morale, which can be explained by the audience's basic psychological needs: on the one hand, they need to be convinced of the severity of the disease in order to comply with regulations; on the other hand, struck by social restrictions and economic disaster, they have to believe in a successful outcome in order to maintain a bearable state of mind.

In times of crisis, political communication changes significantly; perhaps the most obvious shift stems from the rhetors' increased reliance on emotion in order to win over audiences. People's emotional responses override rational ones even in normal times; even more so, when countries worldwide face an unprecedented, twofold threat (medical and economic). "What's important is that communication is handled. But what's even more important is that it is handled". (Helfert, 2018: 259) In other words, in order to inform and, most imperatively, reassure and persuade people, in order to ensure cooperation and social order, a constant flow of information must be provided; equally, it must be handled in a thorough, tactful way. Both stopping the information flow and losing control thereof represent dangerous possibilities in times when people suffer physically, financially, socially and emotionally. The only thing to do when disaster looms is to constantly communicate with your audience, striking the right balance between the emotions you arouse (in particular, striking the right balance between fear and hope) and, above all else, let them know that you are tackling the problem and the crisis will end as soon as possible. Making people believe that there is a plan, that the leaders are neither erratic nor confused and that they have the knowledge and the expertise to get things back on track are strategies that will both result in social order and compliance, and bestow credibility and legitimacy upon political actors. 
The rhetoric focusing on appeals to unity and action also appears in the discourse of supranational organisations representatives:

Ex. 8

During this crisis, Europe has become the world's beating heart of solidarity. It's time to put behind old divisions, disputes, recriminations and be ready for this new world. We need all the power and strength to make our economies, societies and way of life more sustainable and resilient. (Ursula von der Leyen, Instagram, April 16, $2020^{15}$ )

There are several reasons why the extract above is different from the others analysed so far. Firstly, although Ursula von der Leyen is a German politician, she is also President of the European Commission as of December 2019; hence, she now speaks on behalf of the European Union, an organization that has come under important scrutiny in recent years and whose worldwide importance has been said to be declining, against the background of rising nationalism and in the wake of Brexit, while rumours circulate that other countries might follow suit. Though the European Union is undoubtedly a powerful force in the world's economic, military, social, political and ideological network, the recent electoral victories of nationalistic parties have shed doubt on its legitimacy of late. Indeed, in recent years, confronted with universal problems such as the migrant crisis, globalization, the dilution of national identity, the weakening of countries' own institutions and legislation as against supranational ones, there has been "a recent boom in voter support for rightwing and populist parties ${ }^{16}$,

There are voices claiming that the institution as such faces both a legitimacy crisis (in that average citizens do not have a say in what goes on and is decided in Brussels), and a democratic deficit (Mounk, 2020); thus, the groundbreaking project that is the European Union, an organization initially aiming to unite a continent long haunted by enmity and warfare, seems to be facing an unprecedented crisis because, although "European countries undoubtedly share a common set of cultural and political practices that come from the continent's successive moments of division and pacification, of fragmentation and unification", Europe is no longer the unchallenged center of the world. "Although Europe's power is still strong in absolute terms, it is declining fast in relative terms". (Merand, 2015) Whilst the EU still enjoys international influence blatantly disproportionate with its share of the population, it appears that this is increasingly due to its ideological influence and technological advancement, rather than to its actual economic and military strength.

15 https://www.instagram.com/p/B_DdO1nJDMP/, accessed on May 12, 2020.

16 "Europe and right-wing nationalism: a country-by-country guide", retrieved from https://www.bbc.com/news/world-europe-36130006, accessed on April 20, 2020. 
Representatives of supranational organisations are forced to confront the shift in social paradigm head-on. In extract (8), the speaker invokes the "old divisions" as a challenge that needs to be overcome, if the institution is to stand a chance of defeating the new, overpowering threat of the virus. Everything that might have divided the continent up until this point fades in the face of the new menace - the approach implicitly emphasizes the severity of the crisis, thus also implicitly legitimizing any measures implemented to succeed. Also, the speaker sets the stage for the new concept introduced, that of the "new world". Indeed, reference to an emerging new world where our outlook on life, work, health and social relations has to fundamentally change, redefining the way we live altogether, has been a recurring topic throughout political discourse tackling the coronavirus situation.

Audiences worldwide are not given many details as to what the new world will look like; however, we are compelled to infer that it will be defined within the parameters of a paradigm involving social distancing and an increased percentage of our activities relying on online rather than face-to-face contact and interaction. In extract (8), Ursula von der Leyen legitimizes her discourse, alongside the authority of the institution she represents, by using a metaphor (the world's beating heart of solidarity) which plays on the same overpowering notion of solidarity. Strength and resilience are also reinforced, while the idea that a change is inevitable is conveyed both explicitly, as explained above, and implicitly (we are led to infer that life as we have known it so far has been neither sustainable, nor resilient enough). Thus, the discourse of the representative of a still powerful supranational organization reiterates and underpins the topics omnipresent in the discourse of national leaders, paving the way for audiences to grasp the message that a major change is unavoidable. Hence, both the new way of life and the new mentalities are being shaped through an all-pervasive discourse whose importance and impact remain for history to judge.

\section{Concluding remarks}

The challenge that humanity faces these days is tremendous, both medically and economically. Never in the last century have we been faced with a crisis of this magnitude. On the one hand, the rapid spread of the virus and the violence with which some cases have escalated, requiring intensive care treatment, have taken medical systems worldwide by storm. On the other hand, the total lockdown that most countries have had to implement is bound to result in a recession that IMF specialists predict will outweigh the one in 1929 (Rappeport and Smialek, 2020). Faced with a situation that no one was prepared for, political speakers across the board are tackling the challenge the only way possible: firstly, they show their audiences that they are getting involved, that they are committed to solving the problem and that, in order to do that, they need the support of the community. They establish a constant connection with their followers, organizing their discourse along 
two main dimensions: reinforcing the severity of the crisis while also making room for optimism, for showing the light at the end of the tunnel if citizens cooperate and comply with the strict regulations enforced. Secondly, and perhaps more importantly, they reinforce the idea that that there is a need for new ways of looking at the world, at our lifestyles, at social interaction.

More and more frequently do we hear direct or indirect references to a newly emerging social paradigm, to a different manner of imagining the world, its institutions, and the workplace. Major international events are known to change social customs and redefine mentalities; from that viewpoint, judging by what has happened so far and by how our lives are changing already, we have every reason to believe that the coronavirus crisis will make no exception: it will bring about a major societal shift. The new world will either be a better, more sustainable one, or it will not exist at all.

\section{References and bibliography}

Bailey, G. 2018. "Britons afraid to show national pride in public for fear of ridicule or abuse, poll finds", retrieved from https:/www.independent.co.uk/news/ uk/home-news/patriotism-uk-national-pride-ridicule-abuse-racismxenophobia-prejudice-a8312786.html, accessed on April 11, 2020.

Chilton, P. 2006. Analysing Political Discourse - Theory and Practice, London and New York: Routledge.

Koshik, I. 2005. Beyond Rhetorical Questions, London: John Benjamins PublishingCo.

Denton, R.E, Trent, J.S., and R.V. Friedenberg. 2020. Political Campaign Communication: Principles and Practices, Lanham: Rowman \& Littlefield.

Domenach, J.M. 2004. Propaganda politică, Iași: Institutul European.

Enache, A. 2017. Discursive Practices in Barack Obama's State of the Union Addresses, Saarbrucken: Lambert Academic Publishing.

Enache, A. and M. Militaru. 2013. Political Communication, București: Editura Universitară.

Van Dijk, T. A. 1988. News as Discourse, New Jersey: Lawrence Erbaum Associates.

Van Dijk, T. A. 2004. "Critical Discourse Analysis", in Schiffrin, D., Tannen, D. and H.E. Hamilton (eds.), The Handbook of Discourse Analysis, Oxford: Blackwell (pp. 352-371).

Fairclough, N. 1989. Language and Power, London: Longman.

Gainous, J. and K. Wagner. 2014. Tweeting to Power: The Social Media Revolution in American Politics, New York: Oxford University Press.

Helfert, D.L. 2018. Political Communication in Action - From Theory to Practice, Boulder: Lynne Rienner Publishers. 
Horsman, M. and Marshall, A. 1995. After the Nation - State: Citizens, Tribalism and the New World Disorder, London: Harper Collins Publishers.

Lilleker, D.G. 2006. Key Concepts in Political Communication, London: Sage Publications.

Little, S. 2020. “Approval of prime minister, premier soars amid coronavirus response, Ipsos poll”, retrieved from https://globalnews.ca/news/6792350/ coronavirus-poll-prime-minster-premier-approvals/, accessed on April 25, 2020.

Marcus, G.E. 2000. "Emotions in Politics", in Annual Review of Political Science, 3: 221-250, retrieved from http:/www.annualreviews.org/doi/abs/ 10.1146/annurev.polisci.3.1.221, accessed on October 28, 2017.

Matthews, O. 2020. "Britain Drops Its Go-It-Alone Approach to Coronavirus", retrieved from https://foreignpolicy.com/2020/03/17/britain-uk-coronavirusresponse-johnson-drops-go-it-alone/, accessed on April 11, 2020.

Merand, F. 2015. "The Decline of the European Union: Insights from Historical Sociology", retrieved from http://aei.pitt.edu/79439/, accessed on April 17, 2020 .

Merchan, L. 2018. “On Digital Strategy, Too Many Campaigns Still Don’t Get It”, retrieved from https://www.campaignsandelections.com/campaigninsider/on-digital-strategy-too-many-campaigns-still-don-t-get-it, accessed on April 3, 2020.

Mounk, Y. 2020. “The European Union's Double Crisis of Legitimacy”, retrieved from https://www.theatlantic.com/ideas/archive/2020/01/future-europeanunion/605839/, accessed on April 20, 2020.

Potsar, A. 2016. "Failed communication leads to crisis or crisis leads to failed communication?", in Luengo, O.G. (ed.), Political Communication in Times of Crisis, Berlin: Logos Verlag: 17-39.

Rappeport, A. and J. Smialek. 2020. "IMF Predicts Worst Downturn Since the Great Depression", retrieved from https://www.nytimes.com/2020/04/14/us/ politics/coronavirus-economy-recession-depression.html, accessed on April 20, 2020.

Schiffrin, D. 1998. Approaches to Discourse, Oxford: Blackwell.

Shear, M.D. and D.G, Jr., McNeil. 2020. "Criticized for Pandemic Response, Trump Tries Shifting Blame to WHO", retrieved from https:/www.nytimes.com/2020/04/14/us/politics/coronavirus-trump-whofunding.html, accessed on April 25, 2020.

Wheeldon, T. 2020. "Coronavirus crisis throws a lifeline to Macron's troubled presidency", retrieved from https:/www.france24.com/en/20200405-frances-coronavirus-crisis-throws-lifeline-to-macron-s-troubled-presidency, accessed on April 25, 2020.

Wilson, J. 2004. "Political Discourse", in Schiffrin, D., Tannen, D. and H.E. Hamilton (eds.), The Handbook of Discourse Analysis, Oxford: Blackwell (pp. 398-415). 


\section{Internet sources}

"Flattening the Coronavirus Curve", retrieved from https://www.nytimes.com /article/flatten-curve-coronavirus.html, accessed on April 4, 2020.

“The Queen's Coronavirus Speech", retrieved from https:/www.bbc.com/news/uk52176209, accessed on April 11, 2020.

"Europe and right-wing nationalism: a country-by-country guide", retrieved from https://www.bbc.com/news/world-europe-36130006, accessed on April 20, 2020. https://twitter.com/HillaryClinton, accessed on April 20, 2020.

https://twitter.com/TeamTrump, accessed on May 4, 2020.

https://www.facebook.com/klausiohannis, accessed on May 7, 2020.

https://www.instagram.com/p/B-byJwVA0_C/, accessed on May 8, 2020. https://www.instagram.com/p/B-22HTTgmt4/, accessed on May 9, 2020.

https://www.facebook.com/EmmanuelMacron, accessed on May 11, 2010. https://www.instagram.com/p/B_DdO1nJDMP/, accessed on May 12, 2020.

https://www.instagram.com/p/B-YKboQho8A/?igshid=ibe084reo9d2, accessed on May 12, 2020.

https:/www.instagram.com/p/B-apLM3hldY/?igshid=1oa4wq8thrp2e, accessed on May 12, 2020.

https://twitter.com/WhiteHouse45, accessed on May 14, 2020.

https://twitter.com/realDonaldTrump, accessed on May 14, 2020.

\section{The Authors}

Antonia Enache is an Associate Professor with the Department of Modern Languages and Business Communication at the Bucharest University of Economic Studies. She holds a PhD in Philology from the University of Bucharest (2006), an MA in European and International Relations and Management (University of Amsterdam, 2001) and an MA in Applied Linguistics (University of Bucharest, 1998). She is the author of several books in the field of political communication, such as Discursive Practices in Barack Obama's State of the Union Addresses (2017), Political Communication (co-author, 2013) and Promisiunea politică (2006) and has made numerous contributions to specialized scientific journals. Her main areas of interest include applied linguistics, political communication, economics, business communication and translation studies.

Associate Professor Marina Militaru, PhD, is the author of many articles on political communication and English methodology. Among the books she has published as coauthor we mention Verbal versus nonverbal în comunicarea politică (2016) and Political Communication (2013). She currently teaches Business English at the Bucharest University of Economic Studies. 